\title{
On Gelsemium and Complementary and Alternative Medicine (CAM) in Anxiety and Experimental Neurology
}

Salvatore Chirumbolo

To view enhanced content go to www.neurologytherapy-open.com Received: November 12, 2014 / Published online: December 19, 2014

(c) The Author(s) 2014. This article is published with open access at Springerlink.com

\section{ABSTRACT}

A recent discussion expanded the debate about the experimental research on Gelsemium in anxiety. Herbal medicine is widely used in anxiety and mood disorders, often with contradictory evidence, although some authors are yet prompted to promote their full introduction in pharmacology as a promising therapy. Complementary and alternative medicine (CAM) in anxiety is particularly appreciated by individual healthcare, but deserves further investigation, as many critical issues have been recently raised. Comments about the ability of negligible doses of Gelsemium hydroalcoholic extracts to affect gene expression were recently reported.

Keywords: Gelsemium; Gelsemine; GABA receptors; Behaviour; Anxiety

S. Chirumbolo $(\square)$

Department of Medicine, Univerity of Verona,

LURM Est Policlinico GB Rossi, Piazzale AL Scuro 10, 37134 Verona, Italy

e-mail: salvatore.chirumbolo@univr.it

\section{INTRODUCTION}

Herbal medicine is widely used in anxiety and mood disorders, often with contradictory evidence [1], although some authors are yet prompted to promote their full introduction in pharmacology as a promising therapy [2, 3]. Complementary and alternative medicine (CAM) in anxiety is particularly appreciated by individual healthcare [4], but deserves further investigation, as many critical issues have been recently raised. $[5,6]$. As a matter of fact, a recent discussion expanded the debate about the experimental research on Gelsemium in anxiety [7-11]. This Commentary tries to elucidate major issues causing this debate by addressing the numerous aspects raised in comments published elsewhere in the literature.

The anxiolytic property of Gelsemium plant has been extensively reviewed [11-14]. Raw alcoholic extracts from Gelsemium sempervirens showed the ability to modify the response of mice in behavioural tests and reduce anxiety [15]. In this research, the anxiolytic property related to Gelsemium extracts has been quite exclusively associated with the alkaloid gelsemine $[13,15,16]$; yet, Gelsemium plants 
contain many further alkaloids with anxiolytic potential [12], thus suggesting that the antianxiety activity of Gelsemium sempervirens may come indifferently from gelsemine, koumine, or gelsevirine or a complex mixture of several active alkaloids [13]. Actually, plants from the genus Gelsemium are considered a source of potential anxiolytic substances [12]. This means that experimental neuroscience based on the possible use of Gelsemium as a CAM therapy for anxiety shows many difficulties in highlighting a single active principle accounting for the presumptive evidence of efficacy observed in in vitro and animal models. The current debate on Gelsemium and anxiety includes the many issues exemplified in Table 1, where bias, comments, and replies to comments are thoroughly summarized. A comprehensive neuropharmacology of Gelsemium should take into consideration any aspect coming from issues described within the reported table.

Most of articles dealing with Gelsemium in anxiety pertain to CAM therapy. A Pubmed/ Medline search of the MESH term Gelsemium allowed us to retrieve 121 papers from 1945 to date, of which 83 dealt with Gelsemium in herbal medicine and CAM. The excellent journal Psychopharmacology published at least two papers about Gelsemium in homeopathy $[15,17]$, showing either a cataleptogenic or anxiolytic action by Gelsemium $30 \mathrm{cH}$, i.e. a theoretical gelsemine concentration less than $6 \times 10^{-60} \mathrm{~mol} / \mathrm{L}$ [15]. In this circumstance, it should be quite difficult to associate any neurologic effect whatsoever with any active molecule present in serially diluted extracts from the Gelsemium plant. Moreover, comments were raised about the presence of ponderable, significant moles of ethanol added as a co-solvent with water $[9,10,18,19]$. While a Gelsemium 30CH might have negligible traces of possible active principles, its ethanol content would be within the range $0.5-1.0 \mathrm{mM}$ [18], an occurrence that raised comments about the active molecule in the observed and reported effects $[15,18-21]$. These issues prompted this author to address the debate about Gelsemium in the following step-points.

This article is based on previously conducted studies, and does not involve any new studies of human or animal subjects performed by the author.

\section{ACTIVE PRINCIPLES, SOLVENT, AND MECHANISM OF ACTION}

Alcoholic raw extracts from plants contain alkaloids and other molecules that may interfere with a plain interpretation of the pharmacology of active principles, due to the complex interaction, either synergistic or competitive, existing between different substances in the raw mixture [11]. Particularly, gelsemine has been recently associated with a well-defined neuropharmacological mechanism related with anxiety. It modulates anxiety in laboratory animals at a sub-micromolar dose range, and in fact, gelsemine doses from $10^{-6}$ to $10^{-10} \mathrm{M}$ induce an anxiolytic action in rats in the elevated plus-maze test [13]. Gelsemine is a Gelsemium derived alkaloid sharing a chemical and functional kinship with strychnine [22]. In rat spinal cords, gelsemine showed an additive effect with glycine in increasing the production of the neurosteroid allopregnenolone $(3 \alpha, 5 \alpha$ tetraidroprogesterone or $3 \alpha$-idrossi- $5 \alpha$-pregnan20-one, $3 \alpha, 5 \alpha$-THP), which in turn should increase anxiety, due to an increased hippocampal expression of $\alpha 4 \beta \delta$ GABAA receptors [23, 24]. $3 \alpha, 5 \alpha-\mathrm{THP}$ is a positive 
Table 1 Fundamental issues in the research about Gelsemium and anxiety

\begin{tabular}{|c|c|c|c|}
\hline Topic & Issues and bias & References & $\begin{array}{l}\text { (A) Comments } \\
\text { and (B) replies } \\
\text { in: }\end{array}$ \\
\hline Active principles & $\begin{array}{l}\text { Gelsemine (3-ethenyl-1-methyl-2,3,3a,7,8,8a-hexahydro- } \\
1 \text { h,5 h-spiro[3,8,5-(ethane[1,1,2]triyl)oxepino[4,5- } \\
\text { b]pyrrole-4,3'-indol]-2' }\left(1^{\prime} \text { h)-one) was the only active }\right. \\
\text { principle described in the behavioural research } \\
\text { - BIAS } 1 . \text { Gelsemium plant extracts contain other alkaloids } \\
\text { with anxiolytic activity (e.g. koumine, gelsevirine) } \\
\text { - BIAS } 2 \text {. The anxiolytic activity of Gelsemium alcoholic } \\
\text { extracts was not further dissected in order to identify one or } \\
\text { more coworking active principles; } \\
\text { - BIAS 3. Gelsemine was supposed to be the only active } \\
\text { principle working in Gelsemium extracts on the simple basis of } \\
\text { previous in vitro pharmacological evidence } \\
\text { - BIAS 4. Adverse effects not evaluated }\end{array}$ & $\begin{array}{l}{[15,21,} \\
40]\end{array}$ & $\begin{array}{l}A[9] \\
B[10]\end{array}$ \\
\hline $\begin{array}{l}\text { Solvent and test } \\
\text { samples }\end{array}$ & $\begin{array}{l}\text { Gelsemium extracts were used as a } 30 \% \mathrm{EtOH} / \text { water mixture } \\
\text { and further diluted with } \mathrm{EtOH} \text { and water to have test samples } \\
\text { - BIAS 5. Refs }[15,16,20,21] \text { started from a raw EtOH/H2O } \\
\text { Gelsemium extract containing } 30 \% \text { alcohol }(\sim 50 \mathrm{mM} \\
\text { EtOH), then a } 1: 100 \text { dilution into water with } 30 \% \mathrm{EtOH} \\
\text { and a } 1.100 \text { dilution into water }(1: 10,000) \text { followed. Final } \\
\text { dilution contained } \sim 500 \mu \mathrm{M} \mathrm{EtOH} \text {, still biologically active } \\
\text { - BIAS } 6 \text {. Ethanol is effective on gene expression at molar } \\
\text { concentrations as low as } 250 \mu \mathrm{M}\end{array}$ & $\begin{array}{l}{[14-16} \\
20,21]\end{array}$ & $\begin{array}{l}\mathrm{A}[8,9,18] \\
\mathrm{B}[10,19]\end{array}$ \\
\hline $\begin{array}{l}\text { Experimental setting } \\
\text { (a): animal model }\end{array}$ & $\begin{array}{l}\text { Animal models: mouse } \\
\text { - BIAS } 7 \text {. Behavioural tests were performed on mice and } \\
\text { in vitro confirmatory cellular tests on humans } \\
\text { - BIAS } 8 \text {. Behavioural tests performed did not include specific } \\
\text { tests on anxiety, depression, sedation } \\
\text { - BIAS 9. Operators treating animals performed behavioural } \\
\text { tests }\end{array}$ & {$[15,16]$} & $\begin{array}{l}\mathrm{A}[8,9] \\
\mathrm{B}[10]\end{array}$ \\
\hline $\begin{array}{l}\text { Experimental setting } \\
\text { (b): in vitro cell } \\
\text { model }\end{array}$ & $\begin{array}{l}\text { In vitro cell model: human neuroblastoma cell line } \\
\text { - BIAS } 10 . \text { Criticism in gene expression performing and } \\
\text { interpretation }\end{array}$ & {$[20,21]$} & $\begin{array}{l}\mathrm{A}[18] \\
\mathrm{B}[19]\end{array}$ \\
\hline
\end{tabular}


Table 1 continued

\begin{tabular}{|c|c|c|c|}
\hline Topic & Issues and bias & References & $\begin{array}{l}\text { (A) Comments } \\
\text { and (B) replies } \\
\text { in: }\end{array}$ \\
\hline $\begin{array}{c}\text { Pharmacological } \\
\text { interpretation }\end{array}$ & $\begin{array}{l}\text { Associated exclusively with gelsemine and considering the } \\
\text { allopregnenolone/GABAR pathway } \\
\text { - BIAS } 11 \text {. The anxiolytic activity of Gelsemium may derive } \\
\text { from other alkaloids besides gelsemine } \\
\text { - BIAS } 12 \text {. Gelsemine can be anxiolytic through a GlyR/ } \\
\text { GlyT1-mediated mechanism } \\
\text { Dilutions and ponderal chemistry. Solvents } \\
\text { - BIAS } 13 \text {. Pharmacological interpretation may be hindered by } \\
\text { diluted test solutions with negligible amounts of active } \\
\text { principles } \\
\text { - BIAS } 14 \text {. Ethanol amount is much more higher than any } \\
\text { Gelsemium derived active principles in tested solutions besides } \\
\text { Gelsemium } 2 \mathrm{CH}\end{array}$ & {$[15]$} & $\begin{array}{l}\text { A }[8,18] \\
\text { B }[19]\end{array}$ \\
\hline Statistics & $\begin{array}{l}\text { Statistics with pooling data } \\
\text { - BIAS 15. Pooling data projected to retrieve positive } \\
\text { evaluation of the mechanism } \\
\text { - BIAS 16. Blinded confounders with the same operator in } \\
\text { treating and performing test with animals }\end{array}$ & [15] & $\begin{array}{l}A[8] \\
B[10]\end{array}$ \\
\hline
\end{tabular}

modulator of GABAA receptors and may cause anxiogenic and adverse mood effects in particular circumstances involving steroid withdrawal [25]. The effect of $3 \alpha, 5 \alpha$-THP on GABAA receptors is particularly complex in neuroscience and depends on the many factors related to chronic stress, the expression level of the GABA receptor $\alpha 4$ subunit, the direction of chloride-mediated ionic fluxes created by these target receptors, leading also to a downregulation or dampening in the benzodiazepine ability to modulate this mechanism $[8,25]$. This should suggest that, at least in animal models, the anxiolytic action attributed to gelsemine may be actually caused by other mechanisms, and more caution is requested about a presumptive $3 \alpha, 5 \alpha-\mathrm{THP} /$
GABA relationship with anxiolytic effects. Interestingly, recent reports on the effect of hydroalcoholic extracts from Gelsemium sempervirens on mouse behaviour showed a marked insensitivity of mice to diazepam [26]. In this circumstance, criticism was raised about setting and evaluation of mice stress response in behavioural tests [8, 9]. Furthermore, other alkaloids contained in Gelsemium plants, such as koumine, have been associated with a $3 \alpha, 5 \alpha-$ THP/GABA receptor signaling [26].

Yet, the anxiolytic activity exerted by Gelsemium might be caused by many further mechanisms. Many Gelsemium-derived alkaloids, such as kuomine and gelsenicine $[26,27]$ exert a nociceptive effect. Particularly, gelsemine acts on chronic pain through the 
activation of spinal $\alpha 3$ glycin receptors (GlyR) [22]. This should suggest that the anxiolytic activity associated with Gelsemium may not directly come from GlyR activation, but most probably from the contribution of activated GlyR on the anziolytic activity of glycine transporter inhibitors [28]. Therefore, it is very difficult to highlight the neurological mechanism by which Gelsemium exerts its anxiolytic activity, when Gelsemium extract is used within a micromolar-millimolar range. Furthermore, Gelsemium contains a lot of molecules with sedative, anti-depressant activity [8], for which it is very difficult to ascertain an anxiolytic activity only by widely used, not properly suited behavioural tests $[8,9$, 15]. In this perspective, other components contained in Gelsemium-derived test solutions such as ethanol, may be significantly involved [8]. Describing a comprehensible overview of the anxiolytic activity of Gelsemium extracts, is hampered also by the recent observation that flavonoids, which are present in the Gelsemium plant, may exert an anxiolytic action [29]. Furthermore, the involvement of the GABAergic system in anxiety models is yet controversial, because anxiogenic/anxiolytic activity on GABAergic systems may be modulated by different types of orexins [30]. This strongly suggests that the interpretation of Gelsemium anxiolytic activity by involving a single, defined mechanism [15] may be reductive.

A recent behavioural research on ICR-CD1 mice used an hydroalcoholic extract of Gelsemium sempervirens, which was serially diluted to reach negligible concentrations of potentially bio-active molecules [15]. ICR-CD1 mice are not particularly suited for behavioural tests compared to the more considered C57BL6 J mouse [31]. A large number of the laboratory mice sold and used by investigators around the world are considered to be outbred or random-bred. Popular stocks of such mice in the US include CD-1 (Charles River Breeding Laboratories), Swiss Webster (Taconic Farms), and ICR, and NIH Swiss (both from Harlan Sprague-Dawley). Outbred mice are used for the same reasons as $\mathrm{F}_{1}$ hybridsthey exhibit hybrid vigor with long life spans, high disease resistance, early fertility, large and frequent litters, low neonatal mortality, rapid growth, and large size. However, unlike $\mathrm{F}_{1}$ hybrids, outbred mice are genetically undefined. Nevertheless, outbred mice are bought and used in large numbers simply because they are less expensive than any of the genetically defined strains. These animals are widely used for behavioural tests. Behavioural tests most commonly used, such as the light dark box test (LDBT) or open field test (OFT), should evaluate time spent at light, without hiding into a small pitch dark hole or walking on the centre of an empty arena, as a measure of stress lacking or anxiety absence for tested animals [15], yet these tests are used also to evaluate sedation, fear-related stress and depression [9] and are much less specifically used for anxiety research than others [8].

Test solutions of Gelsemium alcoholic extracts were made by diluting 1:100 solutions starting from a raw material containing $30 \%$ or about $50 \mathrm{mM}$ ethanol $[15,20,21]$. Concentration of gelsemine, a major component of Gelsemium extract, was calculated as low as $6.5 \times 10^{-4} \mathrm{M}$ in the fresh hydroalcoholic raw extract, then diluted 1:100 $\left(6.5 \times 10^{-6} \mathrm{M}\right)$ in $30 \%$ ethanol $(49.93 \mathrm{mmol} / \mathrm{L})$ and significant evidence reported for tested solutions containing an estimated concentration of $6.5 \times 10^{-20} \mathrm{M}$ gelsemine and $4.99 \times 10^{-4} \mathrm{M}$ ethanol $[15,20,21]$. While the final concentration of ethanol (EtOH) at the socalled Gelsemium $2 \mathrm{CH}$ should be as low as 
$5 \times 10^{-6} \quad \mathrm{M}$ and gelsemine calculated as $6.5 \times 10^{-8} \mathrm{M}$ as $2 \mathrm{CH}$ means a final dilution $1: 10,000$, the authors made $1 \mathrm{CH}(1: 100)$ in $30 \%$ ethanol $(50.5 \mathrm{mM} \mathrm{EtOH})$ and $2 \mathrm{CH}$ into water $\left(0.505 \mathrm{mM}\right.$ EtOH, i.e. $5.05 \times 10^{-4} \mathrm{M}$ EtOH) [15, 20, 21]. Therefore, in Gelsemium $2 \mathrm{CH}$, the ratio EtOH/gelsemine was about 10,000:1 [15, 20]. Because any further dilution was made with this approach, this ratio was particularly higher for $\mathrm{EtOH}$ with respect to Gelsemium at $9 \mathrm{CH}$ and even more at $30 \mathrm{CH}$. Comments raised about this alkaloid/ethanol disproportion, which suggested a preponderant role from ethanol respect to Gelsemium components in modifying mice behaviour in a LDBT and OFT [15], also highlighted why the evidence was scarcely reproducible $[9,32]$. The authors claimed their results as promising and explained Gelsemium ability to reduce anxiety in mice by an anxiolytic effect attributed to gelsemine and $3 \alpha, 5 \alpha$-THP [15]. In their paper, the minimal effective concentration of gelsemine, estimated by the iterative dilution process from $6.5 \times 10^{-4}$ $\mathrm{M}$, was much lower the concentration reported in recent studies $[13,15]$.

The same research group recently showed that diluted hydroalcoholic extracts of Gelsemium were able to affect gene transcription in human neuroblastoma models [19-21]. They reported the same gelsemine concentration previously shown [20] and a slight reduction in a microarray gene expression model on human SH-SY5Y neuroblastoma cell line with an estimated concentration of gelsemine as low as $6.5 \times 10^{-9} \mathrm{M}$, hence within ranges previously reported for rats $[13,21]$. A cognate paper, published in a niche journal in CAM research, confirmed the effect of this gelsemine dosage, but highlighted also a significant effect, though slight, with doses decisively much lower than
$6 \mathrm{nM}$ gelsemine [20]. In both papers, a diluted hydroalcoholic extract of Gelsemium downregulated the expression of $49 / 56$ [21] or $45 / 55$ [20] genes in SH-SYS5 neuroblastoma. Published comments addressed the issue that the effect observed on gene expression might be brought up by EtOH carry-over in the test solution, due to the predominant presence of EtOH respect to any molecule of the starting Gelsemium extract [18]. No gene particularly involved in the neurological mechanism underlying the molecular action of Gelsemium alkaloids was up- or downregulated in the experimental research [18, 20, 21].

\section{FURTHER COMMENTS AND CONCLUSIVE REMARKS}

Comments about the ability of negligible doses of Gelsemium hydroalcoholic extracts to affect gene expression were recently reported [18]. In an attempt to highlight possible conclusive remarks on the research about Gelsemium, I will introduce these fundamental concerns.

1. A more general observation of these studies showed that Gelsemium extract did not undergo a thorough chemical analysis of its composition, but many authors attributed any result to the exclusive effect of gelsemine $[15,20,21]$. Gelsemium sempervirens extracts contain alkaloids with an in toto anxiolytic activity, yet a chemical definition of these components needs to be performed [14]. Other oxindole alkaloids contained in Gelsemium extracts besides gelsemine exhibit a neurotropic action [12]. New alkaloids are being discovered and a complex interaction between Gelsemium alkaloids and their metabolites may affect significantly the biological 
response of an organism to plant extracts [33, 34].

2. Tested solutions contain a sizable molar fraction of ethanol, with respect to Gelsemium extract $[13,18]$. The analytical evaluation of gelsemine reported in [21] should refer to the calculation indicated in [15], as the authors did not perform and subsequently describe the concentration of gelsemine in the alcoholic raw extract used for the experiment on gene expression [18, 19]. According to this assumption, a Gelsemium hydroalcoholic extract containing as low as $6.5 \times 10^{-22} \mathrm{M}$ gelsemine and $5.0 \times 10^{-4} \mathrm{M}$ ethanol downregulated the expression of bombesin-like receptor 3 (BRS3) and gastrin-releasing peptide receptor (GRPR) genes in SH-SY5Y cells [20]. Aside from the consideration about which genes are possibly expressed by neuroblastoma in a genomic microarray and how much they are involved in a behavioural mechanism [18], Gelsemium hydroalcoholic extracts appeared to fundamentally affect genes involved in olfactory and tumor-related mechanism [20, 35, 36], while changes in genes related to neurological mechanism involved in anxiety were not reported [18, 19] This evidence apparently discourages the promising role of Gelsemium used in CAM in modulating genes associated with neuroscience and mood disorders. This apparently aspecific activity by even nanomolar concentrations of gelsemine in Gelsemium might be related also to effects coming from other Gelsemium components, their complex interaction or even to alcoholic solvent, past reports have outlined a role for bombesin-like peptides in the neurological control of ethanol toxicity $[37,38]$, so EtOH in test solutions cannot be excluded from any comment about Gelsemium effect. The authors incubated SH-SY5Y cells with Gelsemium hydroalcoholic extracts for $24 \mathrm{~h}$ [20, 21]; ethanol itself may exhibit an activity on neuroblastoma cells at the estimated concentration of this research for that time course [39].

3. While the gross bulk of evidence in this research regards effects with micromolarnanomolar concentrations of Gelsemium alkaloids [12], the lowest doses should raise criticism for an intrinsic difficulty in chemical analysis and for ethanol-related bias. The molar mass of ethanol solvent in tested solutions approaching a theoretical concentration of active principles lower than 1 attomole/L, is at least 16 orders of magnitude higher. As ethanol is a bioactive molecule at relatively low doses [18], its activity on gene expression may be highly complex and unpredictable, both in treated and control cells, so hindering a reliable statistical evaluation of the assay system.

4. Some authors recently reported that "Perhaps we need to remind that normally, when one performs a study of dose-response and the concentration in the highest dose and the dilution factor are known, there is no way to determine the concentration of substances in all successive dilutions..." [19]. This suggests that the way Gelsemium in CAM approaches mood disorders and anxiety needs this standpoint to be addressed and further elucidated.

\section{CONCLUSIONS}

While increasing evidence reports the anxiolytic activity of Gelsemium [1-6, 11, 13, 
14], research on its active principles needs further investigation. A complex panoply of anti-depressant, sedative, anxiolytic, neurotropic, nociceptive, and mood modifier molecules represents the herbal potential of the Gelsemium plant. In this respect, CAMs using Gelsemium should reappraise experimental reports about test setting and molecular models, in order to reduce misinterpretations, comments and bias about the pharmacological interpretation of Gelsemium activity.

\section{ACKNOWLEDGMENTS}

No funding or sponsorship was received for this study or publication of this article. The named author meets the ICMJE criteria for authorship for this manuscript, takes responsibility for the integrity of the work as a whole, and has given final approval for the version to be published.

Conflict of interest. Salvatore Chirumbolo declares no conflict of interest.

Compliance with ethics guidelines. This article is based on previously conducted studies, and does not involve any new studies of human or animal subjects performed by the author.

Open Access. This article is distributed under the terms of the Creative Commons Attribution Noncommercial License which permits any noncommercial use, distribution, and reproduction in any medium, provided the original author(s) and the source are credited.

\section{REFERENCES}

1. Faustino TT, Almeida RB, Andreatini R. Medicinal plants for the treatment of generalized anxiety disorder: a review of controlled clinical studies. Rev Bras Psiquiatr. 2010;32(4):429-36.

2. Mills PJ, Farag NH, Newton RP, Parry BL. Effects of a traditional herbal supplement on anxiety in patients with generalized anxiety disorder. J Clin Psychopharmacol. 2002;22(4):443-4.

3. Qureshi NA, Al-Bedah AM. Mood disorders and complementary and alternative medicine: a literature review. Neuropsychiatr Dis Treat. 2013;9:639-58.

4. Bazzan AJ, Zabrecky G, Monti DA, Newberg AB. Current evidence regarding the management of mood and anxiety disorders using complementary and alternative medicine. Expert Rev Neurother. 2014;14(4):411-23.

5. Ravindran AV, da Silva TL. Complementary and alternative therapies as add-on to pharmacotherapy for mood and anxiety disorders: a systematic review. J Affect Disord. 2013;150(3):707-19.

6. Moss AS, Monti DA, Amsterdam JD, Newberg AB. Complementary and alternative medicine therapies in mood disorders. Expert Rev Neurother. 2011;11(7):1049-56.

7. Paris A, Schmidlin S, Mouret S, Hodaj E, Marijnen P, Boujedaini N, Polosan M, Cracowski JL. Effect of Gelsemium $5 \mathrm{CH}$ and $15 \mathrm{CH}$ on anticipatory anxiety: a phase III, single-centre, randomized, placebocontrolled study. Fundam Clin Pharmacol. 2012;26(6):751-60.

8. Chirumbolo S. Plant-derived extracts in the neuroscience of anxiety on animal models: biases and comments. Int J Neurosci. 2012;122(4):177-88.

9. Chirumbolo S. Gelsemine and Gelsemium sempervirens L. extracts in animal behavioral test: comments and related biases. Front Neurol. 2011;2:31.

10. Bellavite P. Gelsemium sempervirens and animal behavioral models. Front Neurol. 2011;12(2):56.

11. Jin GL, Su YP, Liu M, Xu Y, Yang J, Liao KJ, Yu CX. Medicinal plants of the genus Gelsemium (Gelsemiaceae, Gentianales)—a review of their phytochemistry, pharmacology, toxicology and traditional use. J Ethnopharmacol. 2014;152(1):33-52.

12. Liu M, Huang HH, Yang J, Su YP, Lin HW, Lin LQ, Liao WJ, Yu CX. The active alkaloids of Gelsemium elegans Benth. are potent anxiolytics. Psychopharmacology (Berl). 2013;225(4):839-51.

13. Meyer L, Boujedaini N, Patte-Mensah C, MensahNyagan AG. Pharmacological effect of gelsemine on 
anxiety-like behavior in rat. Behav Brain Res. 2013;253:90-4.

14. Dutt V, Dhar VJ, Sharma A. Antianxiety activity of Gelsemium sempervirens. Pharm Biol. 2010;48(10):1091-6.

15. Magnani P, Conforti A, Zanolin E, Marzotto M, Bellavite P. Dose-effect study of Gelsemium sempervirens in high dilutions on anxiety-related responses in mice. Psychopharmacology. 2010;210(4):533-45.

16. Bellavite $\mathrm{P}$, Magnani $\mathrm{P}$, Marzotto $\mathrm{M}$, Conforti A. Assays of homeopathic remedies in rodent behavioural and psychopathological models. Homeopathy. 2009;98(4):208-27.

17. Sukul NC, Bala SK, Bhattacharyya B. Prolonged cataleptogenic effects of potentized homoeopathic drugs. Psychopharmacology. 1986;89(3):338-9.

18. Chirumbolo S. High diluted molecules and gene expression. Front Pharmacol. 2014;14(5):183.

19. Marzotto M, Olioso D, Bellavite P. Gene expression and highly diluted molecules. Front Pharmacol. 2014;12(5):237.

20. Marzotto M, Olioso D, Brizzi M, Tononi P, Cristofoletti M, Bellavite P. Extreme sensitivity of gene expression in human SH-SY5Y neurocytes to ultra-low doses of Gelsemium sempervirens. BMC Complement Altern Med. 2014;19(14):104.

21. Olioso D, Marzotto M, Moratti E, Brizzi M, Bellavite P. Effects of Gelsemium sempervirens L. on pathwayfocused gene expression profiling in neuronal cells. J Ethnopharmacol. 2014;153(2):535-9.

22. Zhang JY, Gong N, Huang JL, Guo LC, Wang YX. Gelsemine, a principal alkaloid from Gelsemium sempervirens Ait., exhibits potent and specific antinociception in chronic pain by acting at spinal a3 glycine receptors. Pain. 2013;154(11):2452-62.

23. Venard C, Boujedaini N, Belon P, Mensah-Nyagan AG, Patte-Mensah C. Regulation of neurosteroid allopregnanolone biosynthesis in the rat spinal cord by glycine and the alkaloidal analogs strychnine and gelsemine. Neuroscience. 2008;153(1):154-61.

24. Shen H, Mohammad A, Ramroop J, Smith SS. A stress steroid triggers anxiety via increased expression of $\alpha 4 \beta \delta$ GABAA receptors in methamphetamine dependence. Neuroscience. 2013;254:452-75.
25. Smith SS, Ruderman Y, Frye C, Homanics G, Yuan M. Steroid withdrawal in the mouse results in anxiogenic effects of 3alpha,5beta-THP: a possible model of premenstrual dysphoric disorder. Psychopharmacology. 2006;186(3):323-33.

26. Xu Y, Qiu HQ, Liu H, Liu M, Huang ZY, Yang J, Su $\mathrm{YP}, \mathrm{Yu} \mathrm{CX}$. Effects of koumine, an alkaloid of Gelsemium elegans Benth., on inflammatory and neuropathic pain models and possible mechanism with allopregnanolone. Pharmacol Biochem Behav. 2012;101(3):504-14.

27. Liu M, Shen J, Liu H, Xu Y, Su YP, Yang J, Yu CX. Gelsenicine from Gelsemium elegans attenuates neuropathic and inflammatory pain in mice. Biol Pharm Bull. 2011;34(12):1877-80.

28. Komatsu H, Furuya Y, Sawada K, Asada T. Involvement of the strychnine-sensitive glycine receptor in the anxiolytic effects of GlyT1 inhibitors on maternal separation-induced ultrasonic vocalization in rat pups. Eur J Pharmacol. 2014 (in press). doi:10.1016/j.ejphar.2014.11.024.

29. Girish C, Raj V, Arya J, Balakrishnan S. Involvement of the GABAergic system in the anxiolytic-like effect of the flavonoid ellagic acid in mice. Eur J Pharmacol. 2013;710(1-3):49-58.

30. Avolio E, Biasone A, Mele M, Alò R. Distinct anxiogenic/anxiolytic effects exerted by the hamster lateral amygdalar nucleus injected with ORX-A or ORX-B in the presence of a GABAergic agonist. NeuroReport. 2014;25(12):932-7.

31. Kalueff AV, Nguyen M. Testing anxiolytic drugs in the C57BL/6 J mouse strain. J Pharmacol Toxicol Methods. 2014;69(2):205-7.

32. Cervo L, Torri V. Comment on: "Dose-effect study of Gelsemium sempervirens in high dilutions on anxiety-related responses in mice" (Magnani $\mathrm{P}$, Conforti A, Zanolin E, Marzotto M and Bellavite P, Psychopharmacology, 2010). Psychopharmacology (Berl). 2012; 220(2):439-40 (author reply 441-2).

33. Sun M, Hou X, Gao H, Guo J, Xiao K. Two new koumine-type indole alkaloids from Gelsemium elegans Benth. Molecules. 2013;18(2):1819-25.

34. Zhang L, Du L, Lv WW, Zhao QC, Hua W, An Y, Guo T, Wu LJ. Four new koumine metabolites in rat liver microsomes. J Asian Nat Prod Res. 2013;15(1):46-52.

35. Paul P, Qiao J, Kim KW, Romain C, Lee S, Volny N, Mobley B, Correa H, Chung DH. Targeting gastrinreleasing peptide suppresses neuroblastoma 
progression via upregulation of PTEN signaling. PLoS ONE. 2013;8(9):e72570.

36. Monnier J, Samson M. Prokineticins in angiogenesis and cancer. Cancer Lett. 2010;296(2):144-9.

37. Glazner GW, Cannon RL, Kulkosky PJ. Effect of bombesin on behaviors associated with ethanol satiation and blood ethanol levels. Alcohol. 1988;5(4):325-30.

38. Luttinger D, Frye GD, Nemeroff CB, Prange AJ Jr. The effects of neurotensin, beta-endorphin, and bombesin on ethanol-induced behaviors in mice. Psychopharmacology. 1983;79(4):357-63.

39. Lee M, Song BJ, Kwon Y. Ethanol mediates cell cycle arrest and apoptosis in SK-N-SH neuroblastoma cells. J Cancer Prev. 2014;19(1):39-46.

40. Blaw ME, Adkisson MA, Levin D, Garriott JC, Tindall RS. Poisoning with Carolina jessamine (Gelsemium sempervirens [L.] Ait.). J Pediatr. 1979;94(6):998-1001. 